\title{
Who will save the planet?
}

\section{Washington \& London}

THE Bush administration last week received a commitment from countries meeting in Geneva on global climate change to hold a workshop in Washington in October to prepare the ground for a framework convention.

This display of enthusiasm for action on climate change contrasts sharply with an incident earlier in the week, when the White House admitted revising a government scientist's testimony before Congress to present a less gloomy picture of global warming.

The Bush administration was severely criticized last week for altering the testimony of National Aeronautics and Space Administration scientist James Hansen to make his conclusions about greenhouse warming appear less certain (see Nature 339, 84; 11 May 1989). The criticism was especially pointed in light of Bush's campaign rhetoric promising to tackle the problem of greenhouse warming.

At a hastily arranged press conference last Friday, Environmental Protection Agency (EPA) administrator William Reilly denied that the commitment to hold a workshop was a change in direction for the administration, and reiterated Bush's commitment to solving enviromental problems.

The October workshop will address five topics: legal and institutional issues, economic issues, questions of public education, technology transfer and the role of international banks. Each nation attending will prepare papers addressing these topics, which will be used to form a consensus that can be presented to the International Panel on Climate Change (IPCC) in early 1990. By the end of that year, IPCC should be able to move forward with attempts to produce a framework convention that would form an umbrella for protocols to address climate problems.

Reilly said the administration was especially anxious to treat seriously the concern that strict conservation measures may stifle economic growth in developing nations. He denied that the United States is trying to wrest from any other country world leadership in addressing climate change. He maintained that the United States takes global warming seriously, and would encourage others to do so, but would not trivialize the problem by "responding to fashion".

"There is a consensus in the administration that global warming presents a threat to the country and the economy", said Reilly, although he admitted that within the administration there were some differences over how great the threat is. $\mathrm{He}$ insisted that any effective steps to stop global environmental damage will have to be taken in concert by all nations.
The British government is also keen to be seen at the forefront of international activity to tackle the problem of climate change. Britain's environment minister Lord Caithness will attend a meeting of the governing council of the UN Environment Programme (UNEP) in Nairobi this week, where he will report on the outcome of a seminar on climate change convened by the Prime Minister, Mrs Margaret Thatcher, held at her house at 10 Downing Street last month.

Caithness is also expected to endorse the formation of an international conven- tion on climate change that would be followed up with specific regulations, in the same way the Montreal Protocol for the protection of the ozone layer builds on the Vienna Convention.

$\mathrm{He}$ plans to urge that UNEP, which joined with the World Meteorological Organisation to form IPCC, should be strengthened by giving it more resources and greater powers. Britain has just doubled its contribution to UNEP, from $£ 1.25$ million to $£ 3$ million, he said, and other countries should do likewise.

The governing council will also consider how the IPCC can attract greater participation among developing countries.

Joseph Palca \& Christlne McGourty

\section{CHINA}

\section{Student protests bed down}

\section{London}

THE hasty transfer last Monday of China's official welcome to Mr Mikhail Gorbachev from Beijing's Tiananmen Square to Beijing airport is a telling measure of the diffidence of the authorities in dealing with the demonstrating students who had occupied the square. But it is too soon to know how the students' demands for openness and democratization along Gorbachev lines will be dealt with.

The demonstrations began a month ago, after the death on 15 April of $\mathrm{Hu}$ Yaobang, the reformist general-secretary of the Chinese Communist party, who was replaced in January 1987 after a previous wave of student unrest. Many students felt that $\mathrm{Hu}$ had been unfairly ousted, and that he had been let down by insufficiently resolute students and intellectuals. Among the immediate causes of the demonstrations was the failure of the central committee's official obituary of $\mathrm{Hu}$ even to mention his disgrace in 1987.

On 18 April, a student meeting in Tiananmen Square formulated a sevenpoint demand to the authorities, calling for a "reassessment" of $\mathrm{Hu}$ Yaobang's merits and faults, the affirmation of "democracy, freedom, magnanimity and harmony", redress for those wronged in the "anti-spiritual pollution" and "antiliberalization" campaigns of 1987 , an end to corruption among party officials and to press censorship, more money for education and higher salaries for intellectuals.

The same day, Professor Fang Lizhi, the astrophysicist, who lost his university post in the 1987 purge for having allegedly been a harmful political influence on his students, told an Israeli radio reporter that the students had taken the opportunity of Hu's funeral to advocate democracy and freedom.

The authorities were at first unwilling to respond to the students' demands. The new 'student solidarity associations' at
Beijing's universities and higher colleges were denounced as illegal, reports of students injured in clashes with the police were officially denied and (according to a Hong Kong source) the Chinese media were instructed to ignore the students' demands.

A further call for dialogue, made on 21 April by a 100,000 -strong rally, was ignored, whereupon the students went on strike and pasted up around the universities lists of important and well-paid jobs held by the relatives of party leaders. (One was the post of director of the State Commission for Science and Technology, which is held by Deng Nanm, daughter of Deng Xiaoping.)

Dialogue was joined on 29 April, when a government delegation held "frank and sincere" talks with 45 students drawn from 16 Beijing universities and higher colleges (but not, it seems, from the leadership of the new unofficial student unions). The government side afterwards claimed that the wishes of the "broad masses" of the students for the most part coincide with its own, and said that the government had already increased the education budget and was taking measures to rectify its "mistake" in paying intellectuals so little.

Since the early days of this month, mass demonstrations have abated, but petitions for swifter and more effective dialogue continue, while the mood of student criticism and protest has spread to all parts of China, including the ethnic minority areas.

Efforts by the authorities to win the students' confidence by assuring them that no students will be punished for expressing their opinions, provided that they have not broken the law, proved ineffective in ending the protests - possibly because these assurances have been accompanied by condemnation of the new student unions and the demonstrations they organize as "illegal".

Vera Rich 